\title{
Calcein and manganese experiments for marking the shell of the common cockle (Cerastoderma edule): tidal rhythm validation of increments formation
}

\author{
Kélig Mahé1,a ${ }^{1,}$ Elise Bellamy ${ }^{1,2}$, Franck Lartaud $^{3}$ and Marc de Rafélis ${ }^{4}$ \\ 1 IFREMER, Centre Manche-mer du Nord, Sclerochronology Centre, Laboratoire Ressources halieutiques, 150 quai Gambetta, BP 699, \\ 62321 Boulogne-sur-mer, France \\ 2 IFREMER, Centre Manche-mer du Nord, Laboratoire Environnement côtier et Ressources aquacoles, 150 quai Gambetta, BP 699, \\ 62321 Boulogne-sur-mer, France \\ ${ }^{3}$ UPMC Univ Paris 06, CNRS FRE 3350, Laboratoire d'Ecogéochimie des Environnements benthiques (LECOB), Observatoire \\ océanologique, av. du Fontaulé, 66650 Banyuls-sur-mer, France \\ ${ }^{4}$ UPMC Univ Paris 06, UMR 7193, iSTeP, Laboratoire Biominéralisations et Environnements sédimentaires, Case Postale 116, 4 place Jussieu, \\ 75252 Paris Cedex 05, France
}

Received 25 June 2010; Accepted 27 July 2010

\begin{abstract}
This work focuses on investigating the potential of calcein and manganese as growth markers of the common cockle (Cerastoderma edule) in the bay of Somme (France). Recapture of shells, previously marked using a chemical marking and then bred in natural conditions, was performed in order to determine the shell growth patterns. Calcein marking has shown a fluorescent increment in shells after only $30 \mathrm{~min}$ immersion time at $150 \mathrm{mg} \mathrm{L}^{-1}$, but also for shells immersed $3 \mathrm{~h}$ at $50 \mathrm{mg} \mathrm{L}^{-1}$. Likewise, manganese shell marking was revealed under cathodoluminescence for shells immersed $1 \mathrm{~h}$ at $120 \mathrm{mg} \mathrm{L}{ }^{-1}$ as well as for shells which spent $4 \mathrm{~h}$ at $90 \mathrm{mg} \mathrm{L}^{-1}$. A numerical analysis performed on each marked cockles has revealed 23 micro-increments between the mark and the ventral edge of the valves, corresponding to the 23 tides that occurred during the 12 days at liberty post marking. The periodicity of increment formation is thus validated for a tidal frequency. The growth rates of C. edule, ranged from 11.67 to $19.94 \mu \mathrm{m} \mathrm{d}^{-1}$, decreased significantly with increasing shell length. This preliminary study gives a clue to the understanding of cockle growth and could be used in shellfish production for cockle age monitoring, but also for chemical analysis to learn more about biomineralization process of this species.
\end{abstract}

Key words: Calcein / Manganese / Marking / Cathodoluminescence / Shellfish / Cerastoderma edule

Résumé - Cette étude a pour but d'observer le potentiel de la calcéine et du manganèse comme marqueurs de la croissance de la coque commune (Cerastoderma edule) en baie de Somme (France). Pour connaître la croissance, des individus sont dans un premier temps capturés, marqués à l'aide de l'un des marqueurs chimiques et relâchés dans le milieu naturel puis dans un deuxième temps, ils sont recapturés. La calcéine montre une strie fluorescente après seulement 30 minutes d'immersion pour une concentration de $150 \mathrm{mg} \mathrm{L}^{-1}$ et pour $3 \mathrm{~h}$ à $50 \mathrm{mg} \mathrm{L}^{-1}$. De même, une marque due au manganèse est observée en utilisant le procédé de cathodoluminescence pour 1 heure d'immersion à $120 \mathrm{mg} \mathrm{L}^{-1}$ et $4 \mathrm{~h}$ à $90 \mathrm{mg} \mathrm{L}^{-1}$. Une analyse numérique de plusieurs coques marquées a permis de mettre en évidence la présence de 23 stries entre la strie de marquage et le bord de la coquille correspondant à 23 marées et à 12 jours. Ainsi, la périodicité de formation des stries de croissance a été validée avec une fréquence liée à l'oscillation des marées. Les taux de croissance journalière observés de $C$. edule, compris entre 11,67 et 19,94 $\mu \mathrm{m} \mathrm{d}^{-1}$, diminuent significativement avec l'augmentation de la taille de l'individu. Cette étude préliminaire participe à la connaissance de la croissance de la coque commune et pourrait être un outil dans la surveillance des productions de ce bivalve. De plus, en couplant un travail de ce type à une analyse chimique de la coquille, les processus de biominéralisation de cette espèce pourraient être analysés.

a Corresponding author: kelig.mahe@ifremer.fr 


\section{Introduction}

Age determination is basic to understand population dynamics of exploited species and their stock assessment, providing growth rate estimates and longevity by species and area. The common cockle Cerastoderma edule is an estuarial bivalve that is found from the Barents Sea in the North to the Mauritanian coastline in the South. Cockle field production of the bay of Somme, which amounts to 3500 tons annually on average (data from Food and Agriculture Organization), testifies to the commercial extent of this species. Nevertheless, only few studies have been carried out in the past. Current methods for age estimation of bivalves rely on quantification of growth ring on the shell surface or, at a smaller scale, on quantification of the internal micro-growth band, that may be related to periodical phenomena such as tidal or circadian rhythms (Richardson et al. 1979; Lönne and Gray 1988; Kilada et al. 2009). Cockle surface erosion and environmental disturbance may however obscure the identification of external growth rings (Cole 1956; Fahy et al. 2005).

In the recent years, chemical markers have been tested for internal increment identification through a variety of marine animals to validate the age (e.g. fishes, molluscs, echinoderms). Thus, first results in terms of growth rate and localisation of growth zone have been obtained (Kaehler and McQuaid 1999; Pineiro et al. 2007; Ellers and Jonhsson 2009). Organisms exposed to chemical markers incorporate it into the growing calcified structures. An internal growth mark could subsequently be used to investigate growth since the time of the experiment. An efficient marker must present certain characteristics: harmless to the organisms, detectable, easy-touse, long-lasting etc. Several markers were used and experience demonstrated that suitability is species-specific (Bashey 2004; Riascos et al. 2007). The incorporation of the markers in the structure shell is different. Manganese $\left(\mathrm{Mn}^{2+}\right)$ replaces $\mathrm{Ca}^{2+}$ in the carbonate lattice whereas calcein is incorporated into growing calcium carbonate structures (Moran and Marko 2005). Among fluorochromes, calcein presented advantages as little toxicity and reliable marking quality (McKinnon 1996; Riascos et al. 2007). $\mathrm{Mn}^{2+}$ trace element, added to the seawater and incorporated into the shell during biomineralization, proved to be a favourable marker, especially because it is naturally present in seawater and requires low concentration to be effective (Langlet et al. 2006; Barbin et al. 2008; Lartaud et al. 2010). The cathodoluminescence emitted by the shell, previously Mn labeled coupled with geochemical analyses allows to study the relations between the shell biomineralization and the environmental parameters. In the present study, the potential of the fluorochrome calcein and manganese as growth markers has been investigated for the first time on C. edule, looking at the mark quality and the mortality rate depending on concentration and exposure time.

\section{Materials and methods}

\subsection{Study site}

The common cockle, $C$. edule, is the most abundant bivalve in the bay of Somme. The Somme river flows into the English
Channel forming a bay of $76 \mathrm{~km}^{2}$. There is a large fluctuation in the sea level due to the amplitude of the tides from 9 to $10 \mathrm{~m}$. The study site, in the mid-intertidal zone $\left(50^{\circ} 15^{\prime} 65 \mathrm{~N}\right.$; $1^{\circ} 33^{\prime} 20 \mathrm{~W}$ ), was chosen as being representative of other local production yields.

In April 2009, 90 living specimens were collected in the same geographical area from the northern field of the bay (Fig. 1). During the study, a probe recorded the seawater temperature and salinity, with the values range from 12.1 to $13.5^{\circ} \mathrm{C}$ and from 25.8 to $34.2 \%$. The samples represented all cockle length classes (from $1 \mathrm{~mm}$ to $32 \mathrm{~mm}$ in length).

\subsection{Staining experiment}

Cockles were divided into 9 groups of 10 specimens, each with a similar size distribution. The cockles were marked by immersion in seawater containing one of the markers. The seawater used came from the sampling site.

In order to study effects of calcein (CAS 1461-15-0) and manganese $\left(\mathrm{MnCl}_{2}, 4 \mathrm{H}_{2} \mathrm{O}\right)$ on the mark readability and the cockle mortality, various exposure times and concentrations were tested (Table 1) in accordance with previous studies (Thebault et al. 2006; Barbin et al. 2008; Lartaud et al. 2010). Exposure time of $30 \mathrm{~min}$, to achieve the marking in situ during one tide period only, has been performed in order to test the marker limit with regard to C. edule (Day et al. 1995; Riascos et al. 2007).

After the marking experiment, all cockle groups were maintained in fresh seawater, while waiting to be replaced in situ in an experimental structure comprising of 9 different compartments (Fig. 2). Cockles typically live in the top of the substratum, and thus the structure was buried to $50 \mathrm{~cm}$ to prevent the escape of the cockles. As well as burial, the structure has been reinforced by piles of $2.5 \mathrm{~m}$ long in the substratum due to the large tidal range (Fig. 2).

\subsection{Detection and periodicity of growth mark}

After a period of 12 days, all cockles of each group were recaptured and sacrificed. Empty shells were cleaned and oven-dried at $30{ }^{\circ} \mathrm{C}$ for $48 \mathrm{~h}$. To analyse internal microincrements, shells were embedded in epoxy resin, then transversely cut along the growing axis (from the umbo to the ventral margin) using a diamond saw. Thin sections were first mounted in slides with thermoplastic resin (Crystal Bond ${ }^{\mathrm{TM}}$ ), and finally, successively polished with finer grain from 600 to 40000 on both sides. These thin sections with an average thickness of $350 \mu \mathrm{m}$ (from 190 to $450 \mu \mathrm{m}$ ) were observed directly.

Cockles marked with calcein were observed through fluorescence microscopy excitation from 460 to $490 \mathrm{~nm}$ (blue light) and combined with digital camera and computer. Cockles marked with manganese were observed under cathodoluminescence using an optical microscope coupled with a cold cathode (Cathodyne-OPEA, 12-20 keV and 200 to $400 \mu \mathrm{A} \mathrm{mm}{ }^{-2}$ under a pressure of 0.06 Torr). Image analyses were carried out by means of the TNPC software (Calcified Structure Digital Processing, http://noesisvision.com/) in order 


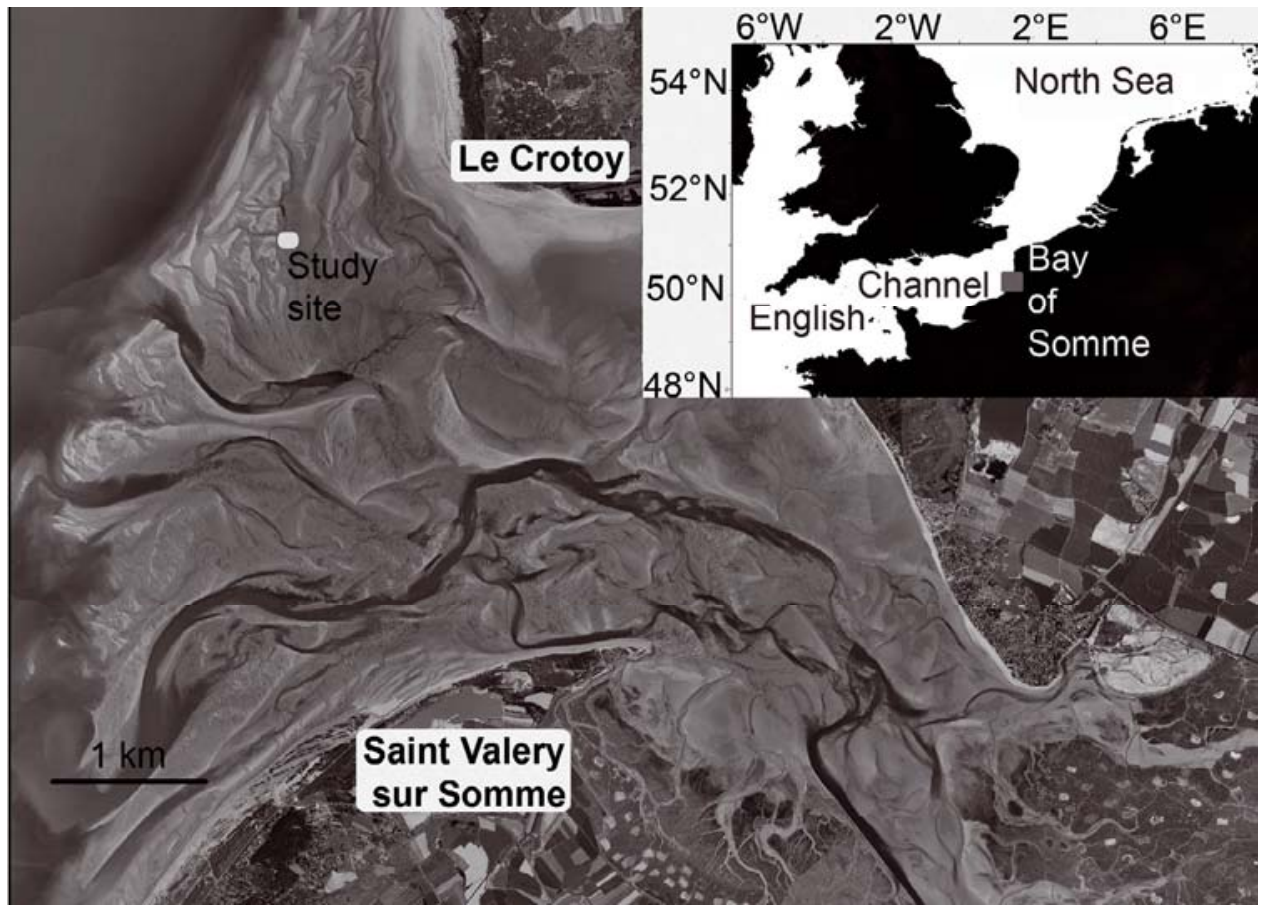

Fig. 1. Study site of C. edule on a fine sand tidal flat in the Bay of Somme (c) Ortho littorale 2000).

Table 1. Quality marking and mortality according to stain type, concentration, exposure time. Mark intensity (in arbitrary units, AU).

\begin{tabular}{ccccccc}
\hline Groups & Marker & $\begin{array}{c}\text { Concentration } \\
\left(\mathrm{mg} \mathrm{L}^{-1}\right)\end{array}$ & $\begin{array}{c}\text { Exposure time } \\
(\mathrm{min})\end{array}$ & Mortality (\%) & Mark quality & $\begin{array}{c}\text { Mark intensity } \\
(\mathrm{AU})(\mathrm{min} / \mathrm{max})\end{array}$ \\
\hline 1 & calcein & 50 & 180 & 0 & clear mark & $13-18$ \\
2 & calcein & 150 & 30 & 0 & clear mark & $36-44$ \\
3 & calcein & 150 & 360 & 0 & clear mark & $43-63$ \\
4 & manganese & 90 & 30 & 0 & no mark & - \\
5 & manganese & 90 & 240 & 0 & clear mark & $6-11$ \\
6 & manganese & 120 & 30 & 0 & no mark & - \\
7 & manganese & 120 & 60 & 0 & clear mark & $19-29$ \\
8 & control & - & - & 0 & - & - \\
9 & control & - & - & 0 & - & - \\
\hline
\end{tabular}
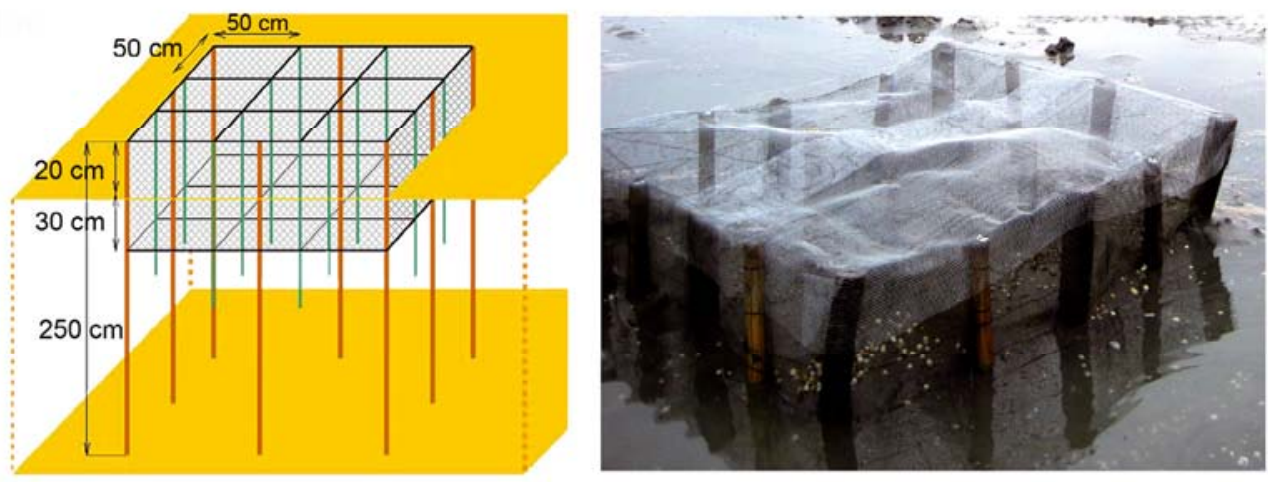

Fig. 2. Details of the experimental structure installed in the Bay of Somme. 
to determine the number of increments mineralized during the 12 days of the experiment. Grey levels have been extracted by image analysis measuring the luminous intensity of each pixel along a radial axis parallel to the growth axis. Grey peaks can be validated as growth increments following simultaneously the grey-scale curve and its location along the radial axis.

This process has been repeated 10 times on each valve of each cockle. Growth rate was calculated using the formula growth rate $\left(\mu \mathrm{m} \mathrm{d}^{-1}\right)=L / D$, where $L$ is the total growth increase and $D$ is the number of days post-treatment. A simple linear regression model was used to relate the shell length to the growth rate.

\section{Results}

No mortality has occurred during the experiment in any of the 9 groups (Table 1). Thus, markers proved not to be lethal at maximal concentrations of $150 \mathrm{mg} \mathrm{L}^{-1}$ for calcein and of $120 \mathrm{mg} \mathrm{L}^{-1}$ for manganese, or for the longest exposure time (340 min for calcein and $240 \mathrm{~min}$ for manganese).

Results of the suitability test of the two stains are summarised in Table 1. Calcein produced a clearly visible fluorescent growth band in shells at all concentrations and exposure time. Fluorescent growth bands were easily identified in all recovered cockles from 30 min with a concentration of $150 \mathrm{mg} \mathrm{L}^{-1}$ (Fig. 3). The intensity of fluorescence is essentially dependent on the calcein concentration; the influence of exposure time appears limited (Table 1). Manganese produced a clearly visible luminescent growth band, easily distinguishable from the natural luminescence for two experiments: concentrations of $90 \mathrm{mg} \mathrm{L}^{-1}$ and $120 \mathrm{mg} \mathrm{L}^{-1}$ and immersion time of $4 \mathrm{~h}$ and $1 \mathrm{~h}$ respectively (Fig. 3). However, the both $30 \mathrm{~min}$ immersion time tests (at $\mathrm{Mn}^{2+}$ concentrations of $90 \mathrm{mg} \mathrm{L}^{-1}$ and $120 \mathrm{mg} \mathrm{L}^{-1}$ ), were not successful, exhibiting dull or no mark for each shell. One hour exposure time seemed to be the lower limit for the incorporation of $\mathrm{Mn}^{2+}$ in the carbonate lattice of the cockle shell. Also, the luminescence emitted by $\mathrm{Mn}^{2+}$ in the shell was green and, thus, indicates the aragonitic microstructure of the calcium carbonate of the cockle shell.

Single marked striae have been identified by fluorescence or cathodoluminescence each time the experiment was successful and the mark was distinguishable almost all along the shell, from the ventral margin to the hinge. Additionally, distinct growth lines are recognized both under fluorescence and cathodoluminescence microscopy (Fig. 3). In each shell section, image analysis identified 23 growth microincrements within the 12 days of the experiment, during which 23 tides occurred (Fig. 4). Consequently, increment deposition of $C$. edule occurs with a tidal periodicity. The daily growth rate or the shell extension rate could be estimated by the growth increment measure between a calcein band and the shell edge. After 12 days, growth rates of $C$. edule ranged from $11.67 \mu \mathrm{m} \mathrm{d}^{-1}$ (5 specimens, mean width: $18.52 \mathrm{~mm}$ ) to $19.94 \mu \mathrm{m} \mathrm{d}^{-1}$ (5 specimens, mean width: $15.38 \mathrm{~mm}$ ). The growth rate does not seem to be influenced by the marking conditions (calcein concentration and exposure time; Figs. 4 and 5). Significantly, the daily growth rate decreased with increasing shell length $(F=39.665 ; p<0.0001)$ (Fig. 5).

\section{Discussion}

\subsection{Marking experiments}

Marking experiments on $C$. edule shells showed difference in quality depending on the stain type, concentration and exposure time. Calcein marking produced a clearly fluorescent band in the shell whatever the marking conditions (Table 1) for all specimens after the 12 days of the experiment. In recent studies on other bivalve growth, calcein exposure time and concentration used varied respectively from 3 to $72 \mathrm{~h}$ and from 10 to $500 \mathrm{mg} \mathrm{L}^{-1}$ (Day et al. 1995; Kaehler and McQuaid 1999; Clarke et al. 2004; Thebault et al. 2006; Riascos et al. 2007; Lucas et al. 2008). In this study, effective fluorescent growth marks were obtained in the same conditions ( $3 \mathrm{~h}$ and $50 \mathrm{mg} \mathrm{L}^{-1}$ ) as Concholepas conconcholepas, Mesodesma donacium (Riascos et al. 2007), Donax hanleyanus and Mesodesma mactroides (Hermann 2008). Moreover, a marking test of $30 \mathrm{~min}$ of immersion at calcein concentration equal to $150 \mathrm{mg} \mathrm{L}^{-1}$, showed a fluorescent mark in all shell specimens. Consequently, in situ calcein marking is efficient and has a time benefit allowing work during one tide period only, and also to limit the stress to the cockle caused by manipulation.

Manganese marking has been carried out in 4 cockle groups. Only 2 experiments revealed a luminescent band clearly separated from natural green luminescence. Manganese experiments demonstrated that $1 \mathrm{~h}$ immersion in seawater enriched with $\mathrm{Mn}^{2+}$ was a minimum for the incorporation of $\mathrm{Mn}^{2+}$ in the carbonate lattice of $C$. edule shell. This exposure time is lower than that commonly used for Haliotis rubra (Hawkes et al. 1997) and Crassostrea gigas (Barbin et al. 2006; Langlet et al. 2006). However, recent works have shown an efficient Mn labelling in C. gigas shells immersed during $30 \mathrm{~min}$ (Lartaud et al. 2010). Contrary to $C$. gigas, $30 \mathrm{~min}$ tests at 2 different concentrations ( 90 and $120 \mathrm{mg} \mathrm{L}^{1}$ ) showed that it was insufficient to incorporate enough $\mathrm{Mn}^{2+}$ by substituting $\mathrm{Ca}^{2+}$ in the crystal lattice of $C$. edule. Nevertheless, the Mn marking compared to methods using chemicals markers such as fluorochromes is more adapted to analyse the biomineralization processes (Langlet et al. 2006).

In some studies, it was found that tetracycline fluorochrome adversely affects the organisms studied and leads to substantial mortality (Nakahara 1961; Schmitt 1984; Monaghan 1993; Pirker and Schiel 1993). Other studies on bivalve growth, suggest that calcein fluorochrome exhibits little toxicity (Day et al. 1995; Rowley and MacKinnon 1995; Kaehler and McQuaid 1999; Moran 2000; Thebault et al. 2006; Riascos et al. 2007). Likewise, in this work, calcein had no lethal effect for all age classes during the whole experiment. Unlike oxytetracycline and tetracycline utilisation which requires $\mathrm{NaOH}$ to increase the rate of survival during the marking (Lucas et al. 2008), calcein use does not necessarily require any other treatment. The same results were obtained for manganese at the concentrations of 90 and $120 \mathrm{mg} \mathrm{L}^{-1}$. 


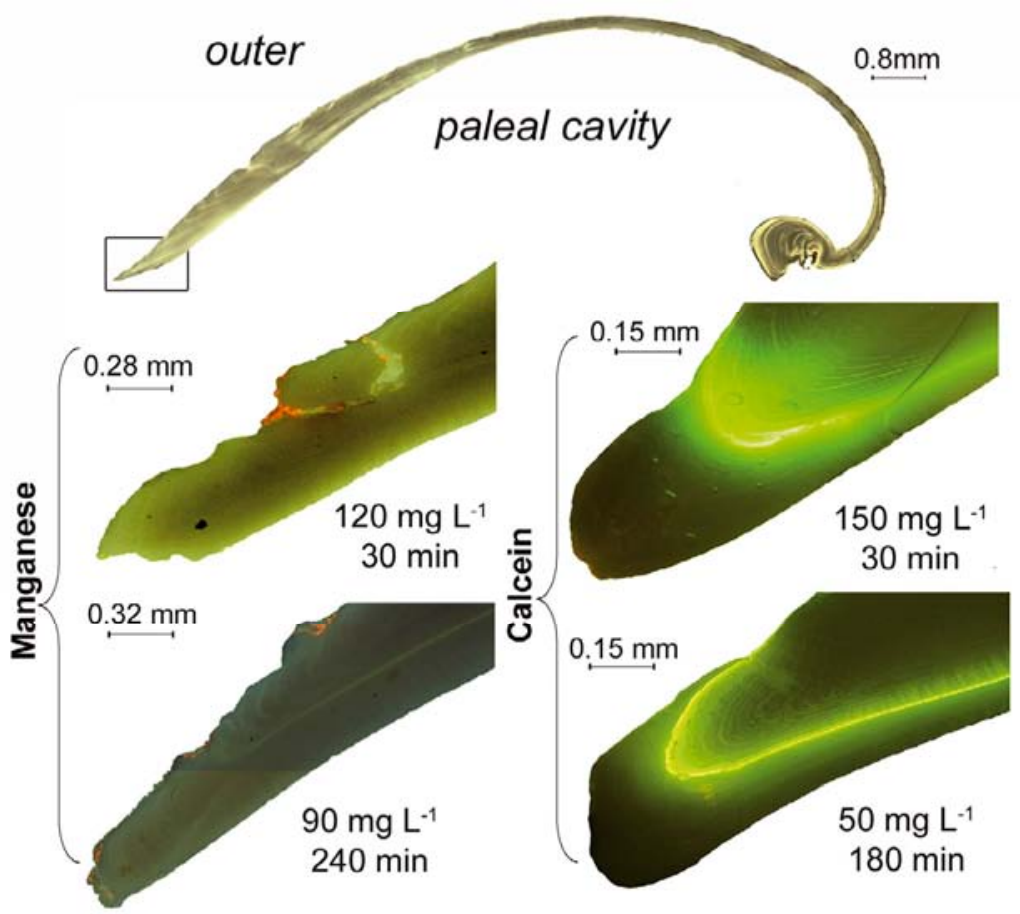

Fig. 3. Images of Cerastoderma edule shell sections after marking-recapture experiment using manganese or calcein (arrows indicate marking bands).

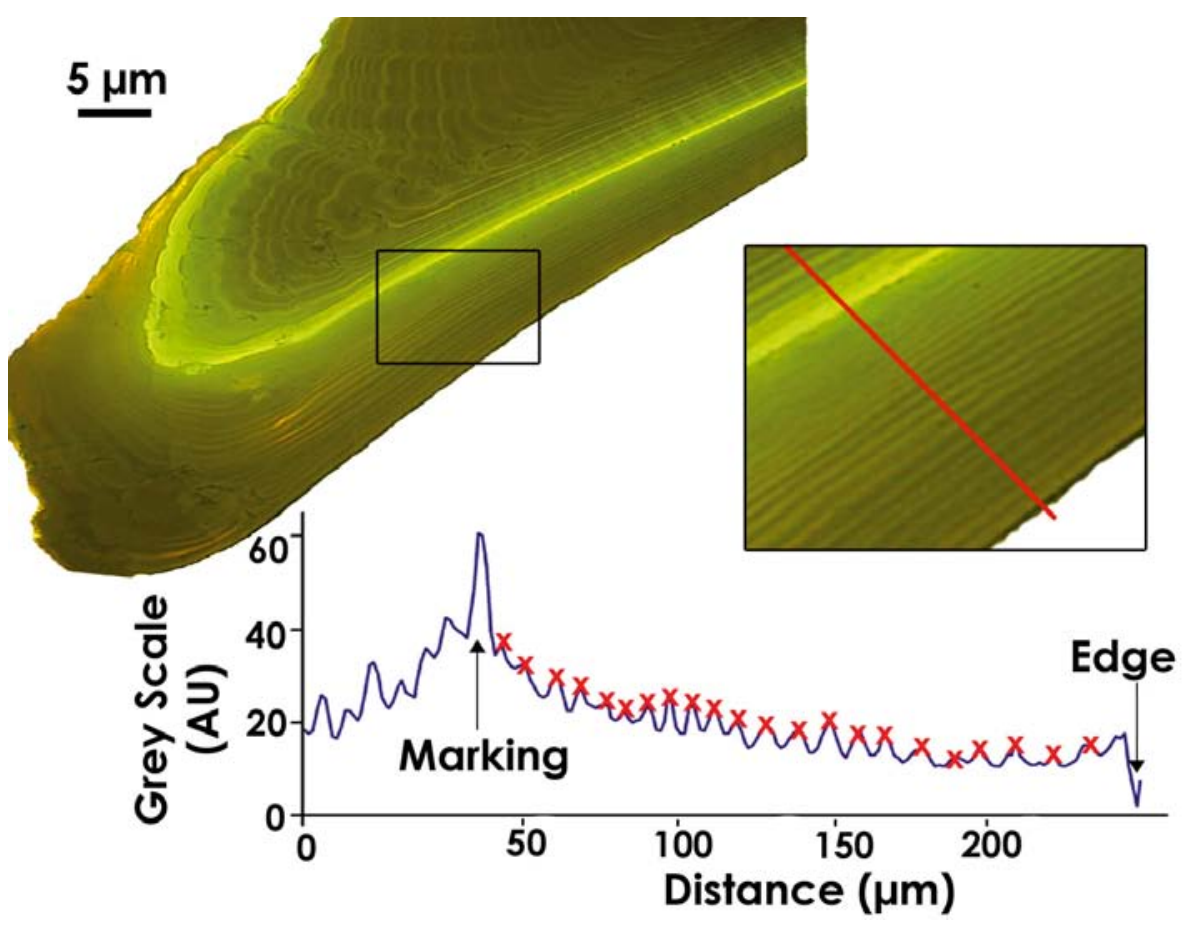

Fig. 4. Magnification of a marked shell edge in C. edule: green fluorescent mark produced during $3 \mathrm{~h}$ in calcein solution $\left(50 \mathrm{mg} \mathrm{L}^{-1}\right)$ and observed growth increments before and after marking. Along a radial axis (red line), grey levels have been measured (AU: arbitrary unit) and each grey peaks is identified (red mark). 


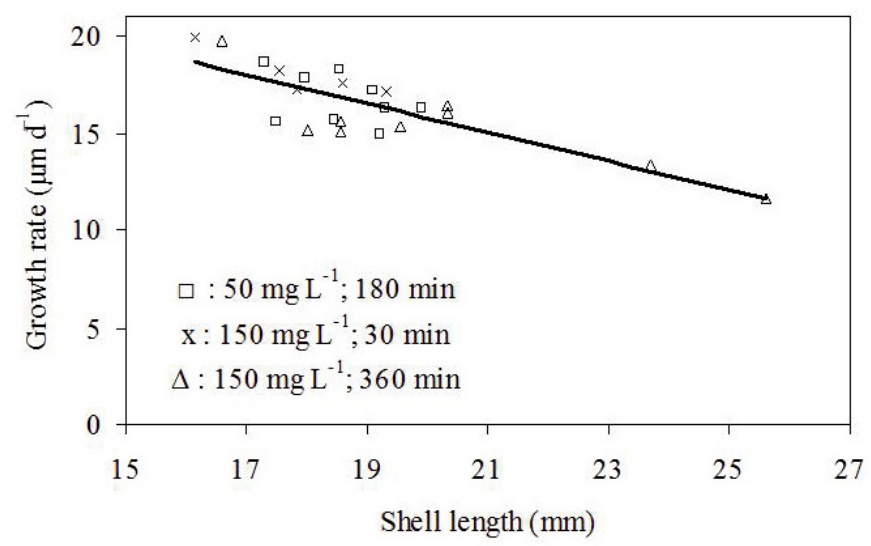

Fig. 5. Growth rate of Cerastoderma edule estimated by calcein marking method during 12 days according to the calcein concentration $\left(\mathrm{mg} \mathrm{L}^{-1}\right)$ and immersion time (minutes). The black line is a linear regression $\left(y=-0.743 \mathrm{x}+30.62\right.$ and $\left.R^{2}=0.65 ; N=23\right)$.

Nevertheless, for abalone, concentrations above $945 \mathrm{mg} \mathrm{L}^{-1}$ were lethal over the immersion period (Hawkes et al. 1997).

\subsection{Tidal rhythm of internal increments formation}

As previously shown for $C$. gigas shells (Langlet et al. 2006; Lartaud et al. 2010), cathodoluminescence appeared as a promise tool for studying shell growth increments in cockles. Moreover, fluorescence analysis of the shells revealed that this method is also relevant for imaging internal growth patterns, as it was recently described in A. islandica bivalve shells (Wanamaker et al. 2009).

Previous studies on $C$. edule growth addressed the increment formation periodicity (Bourget and Brock 1990), debating whether it follows a tidal (Richardson 1979, 1980, 1981; Lönne and Gray 1988) or a circadian rhythm (Cole 1956; House and Farrow 1968). Different methods have been used (cold shock, time-series analysis, external ring census, etc.), which were either inaccurate or stressful for the animals. At present, we are able to determine, via chemical marking, the exact growth that occurred between two dates in natural conditions with a minimum of disturbance. In this way, this study assesses the tidally growth pattern of aragonite increment deposition in $C$. edule shells. This confirms the tidal regime as the main environmental factor dictating the shell growth in intertidal habitats (Schöne 2008). As shell growth of bivalves is limited to high tides (Evans 1972; Goodwin et al. 2001), during aerial exposure at low tide, the animals are forced to keep their valves tightly closed, and retract the mantle into the shell (Clark 1974), leading to shell growth cessation and the formation of a growth line.

Calcein and manganese marking showed no mortality after 12 days of the experiment. In the same way, it could be carried out in several study sites and during a long period to determine growth variations in situ between seasons and habitats, and the influence of environmental parameters such as temperature, immersion time, current flow and trophic conditions (Richardson et al. 1980; Lönne and Gray 1988). Shell growth of Crassostrea gigas was followed by manganese marking which had demonstrated that growth depends on seawater temperature changes (Lartaud et al. 2010).

The daily growth rate of $C$. edule decreased with increasing shell length as for Perna perna (Kaehler and McQuaid 1999), for Ruditapes philippinarum (Fujikura et al. 2003), for Donax hanleyanus and for Mesodesma mactroides (Hermann 2008). House and Farrow (1968) observed population of $C$. edule during 2 years long and growth was faster during the first 2 months after settlement and then decreased. Variations in growth rate of molluscs are controlled by environmental factors and physiological constraints (Wilbur and Owen 1964; House and Farrow 1968; Schöne et al. 2003). During the year, the growth rates of $C$. edule fluctuated, mainly due to the variations of sea temperature and the tidal patterns (Cole 1956; House and Farrow 1968; Lönne and Gray 1988). Our study in April however may not have been representative of the whole year.

\section{Conclusion}

In conclusion and taking into account the results on mark quality and stain effect, both calcein and manganese labelling can be used for shell growth studies, but calcein is recommended as the in situ cockle shell growth marker because of its efficiency after a short exposure time (30 min), compared with the manganese marking (no response at $30 \mathrm{~min}$ ). Detection of tidal growth rhythms would be a promising tool for age determination and growth rate analyses, as well as for shell micro-sampling strategy for geochemical studies in an environmental monitoring perspective.

Acknowledgements. We are grateful to Alain Lefebvre (IFREMER), Franck Jacqueline (IFREMER), team of Sclerochronology centre (IFREMER), Antoine Meirland (Gemel association) and the sea wardens of Bay of Somme (Philippe Desmaret and Jean-Michel Petit) for their help during the whole marking experiment. We would especially thank Mark Etherton for his valuable help in correcting this manuscript.

\section{References}

Barbin V., Ramseyer K., Elfman M., 2008, Biological record of added manganese in seawater: a new efficient tool to mark in vivo growth lines in the oyster species Crassostrea gigas. Int. J. Earth Sci. 97, 193-199.

Bashey F., 2004, A comparison of the suitability of alizarin red S and calcein for inducing a non-lethally detectable mark in juvenile guppies. Trans. Am. Fish. Soc. 133, 1516-1523.

Clark I.G.R., 1974, Growth lines in Invertebrates skeletons Ann. Rev. Earth Th. Pl. Sci. 2, 77-99.

Clarke A., Prothero-Thomas E., Beaumont J.C., Chapman A.L., Brey T., 2004, Growth in the limpet Nacella concinna from contrasting sites in Antarctica. Polar Biol. 28, 62-71.

Cole H.A., 1956, A preliminary study of growth-rate in cockles (Cardium edule L.) in relation to commercial exploitation. J. Cons. Int. Explor. Mer 22, 77-90.

Day R.W., Williams M.C., Hawkes G.P., 1995, A comparison of fluorochromes for marking abalone shells. Mar. Freshw. Res. 46, 599-605. 
Ellers O., Johnson A.S., 2009, Polyfluorochrome marking slows growth only during the marking month in the green sea urchin Strongylocentrotus droebachiensis. Invertebr. Biol. 128, 126144.

Evans J.W., 1972, Tidal growth increments in the cockle Clinocardium nuttalli. Science 176, 416-417.

Fahy E., Carroll J., Murran S., 2005, The Dundalk cockle Cerastoderma edule fishery in 2003-2004. Irish Fish. Invest. 14, 16.

Fujikura K., Okoshi K., Naganuma T., 2003, Strontium as a marker for estimation of microscopic growth rates in a bivalve. Mar. Ecol. Prog. Ser. 257, 295-301.

Goodwin D.H., Flessa K.W., Schöne B.R., Dettman D.L., 2001, Cross-calibration of daily growth increments, stable isotope variation, and temperature in the Gulf of California Bivalve Mollusk Chione cortezi: Implications for paleoenvironmental analysis. Palaios 16, 387-398.

Hawkes G.P., Day R.W., Wallace M.W., Nugent K.W., Bettiol A.A., Jamieson D.N., Williams M.C., 1996, Analyzing the growth and form of mollusc shell layers, in situ, by cathodoluminescence microscopy and Raman spectroscopy. J. Shellfish Res. 15, 659-666.

Hermann M., 2008, Population dynamics of the Argentinean surf clams Donax hanleyanus and Mesodesma mactroides from openAtlantic beaches off Argentina. Ph.D thesis, Univ. Bremen, Germany.

House M.R., Farrow G.E., 1968, Daily growth banding in the shell of the cockle, Cardium edule. Nature 219, 1384-1386.

Kaehler S., McQuaid C.D., 1999, Use of the fluorochrome calcein as an in situ marker in the brown mussel Perna perna. Mar. Biol. $133,455-460$.

Kilada R., Campana S., Roddick D., 2009, Growth and sexual maturity of the northern propellercalm, Cyrtodaria siliqua, in Eastern Canada with bomb radiocarbon age validation. Mar. Biol. 156, 1029-1037.

Langlet D., Alunno-Bruscia M., De Rafelis M., Renard M., Roux M., Schein E., Buestel D., 2006, Experimental and natural cathodoluminescence in the shell of Crassostrea gigas from Thau lagoon (France): ecological and environmental implications. Mar. Ecol. Prog. Ser. 317, 143-156.

Lartaud F., De Rafelis M., Ropert M., Emmanuel L., Geairon P., Renard M., 2010, Mn labelling of living oysters: artificial and natural cathodoluminescence analysis as a tool for age and growth rate determination of $C$. gigas (Thunberg, 1793) shells. Aquaculture 300, 206-217.

Lönne O.J., Gray J.S., 1988, Influence of tides on microgrowth bands in Cerastoderma edule from Norway. Mar. Ecol. Prog. Ser. 42, $1-7$.

Lucas T., Palmer P.J., Wang S., Scoones R., 2008, Marking the shell of the saucer scallop Amusium balloti for sea ranching using oxytetracycline, calcein and alizarin red S. J. Shellfish Res. 27, $1183-1188$.

McKinnon J.F., 1996, Studies of the age, growth and shell increment patterns in the New Zealand cockle (Austrovenus stutchburyi). Ph.D. thesis, Univ. Otago, New Zealand.
Monaghan J.P., 1993, Comparison of calcein and tetracycline as chemical markers in summer flounder. Trans. Am. Fish. Soc. 122, 298-301.

Moran A.L., 2000, Calcein as a marker in experimental studies newlyhatched gastropods. Mar. Biol. 137, 893-898.

Moran A.L., Marko P.B., 2005, A simple technique for physical marking of larvae of marine bivalves. J. Shellfish Res. 24, 567-571.

Nakahara H., 1961, Determination of growth rates of nacreous layer by the administration of tetracycline. Bull. Nat. Pearl Res. Lab. 6, 607-614.

Pineiro C., Rey J., De Pontual H., Goni R., 2007, Tag and recapture of European hake (Merluccius merluccius L.) off the Northwest Iberian Peninsula: First results support fast growth hypothesis. Fish. Res. 88, 150-154.

Pirker J.G., Schiel D.R., 1993, Tetracycline as a fluorescent shell marker in the abalone Haliotis iris. Mar. Biol. 116, 81-86.

Riascos J., Guzma N., Laudien J., Heilmayer O., Oliva M., 2007, Suitability of three stains to mark shells of Concholepas concholepas (Gastropoda) and Mesodesma donacium (Bivalvia). J. Shellfish Res. 20, 43-49.

Richardson C.A., Crisp D.J., Runham N.W., 1979, Tidally deposited growth bands in the shell of the common cockle, Cerastoderma edule (L.). Malacologia 18, 277-290.

Richardson C.A., Crisp D.J., Runham N.W., 1980, An endogenous rhythm in shell deposition in Cerastoderma edule. J. Mar. Biol. Assoc. UK 60, 991-1004.

Richardson C.A., Crisp D.J., Runham N.W., 1981, Factors influencing shell deposition during a tidal cycle in the intertidal bivalve Cerastoderma edule. J. Mar. Biol. Assoc. UK 61, 465-476.

Rowley R.J., Mackinnon D.I., 1995, Use of the fluorescent marker calcein in biomineralisation studies of brachiopods and other marine organisms. Bull. Inst. Oceanogr. Fish. 14, 111-120.

Schmitt P.D., 1984, Marking growth increments in otoliths of larval and juvenile fish by immersion in tetracycline to examine the rate of increment formation. Fish. Bull. 82, 237-242.

Schöne B.R., Tanabe K., Dettman D.L., Sato S., 2003, Environmental controls on shell growth rates and $\delta 180$ of the shallow-marine bivalve mollusk Phacosoma japonicum in Japan. Mar. Biol. 142, $473-485$.

Schöne B.R., 2008, The curse of physiology-challenges and opportunities in the interpretation of geochemical data from mollusk shells., Geo Mar. Lett. 28, 269-285.

Thebault J., Chauvaud L., Clavier J., Fichez R., Morize E., 2006, Evidence of a 2-day periodicity of striae formation in the tropical scallop Comptopallium radula using calcein marking. Mar. Biol. 149, 257-267.

Wanamaker A.D., Baker A., Butler P., Richardson C.A., Scourse J.D., Ridgway I., Reynolds D.J., 2009, A novel method for imaging internal growth patterns in marine molluscs: a fluorescence case study on the aragonitic shell of the marine bivalve Arctica islandica (Linnaeus). Limnol. Oceanogr. Methods 7, 673-681.

Wilbur K. M., Owen G., 1964, Growth. In: Wilbur K.M., Yonge C.M. (Eds). Physiology of the Mollusca. Academic Press, New York, pp. 211-242. 